\title{
Correction: Phase II trial of natalizumab with corticosteroids as initial treatment of gastrointestinal acute graft-versus-host disease
}

Natasha Kekre • Haesook T. Kim • Julia Hofer • Vincent T. Ho • John Koreth • Philippe Armand $(\mathbb{D} \cdot$ Sarah Nikiforow • Mahasweta Gooptu - Rizwan Romee · Edwin P. Alyea · Prashant Nageshwar • Brett Glotzbecker · Areej El-Jawahri • Zachariah DeFilipp (i) - Robert J. Soiffer - Joseph H. Antin (1) - Yi-Bin Chen (1) - Corey Cutler (1)

Published online: 12 October 2020

(c) The Author(s), under exclusive licence to Springer Nature Limited 2020

Correction to: Bone Marrow Transplantation

https://doi.org/10.1038/s41409-020-01049-0
The original version of the Article stated in the Methods section that Natalizumab was provided by Genentech. In fact, it was provided by Biogen. This has now been corrected in both the PDF and HTML versions of the Article. 